\title{
Erratum to: RIZ1: a potential tumor suppressor in glioma
}

Chenran Zhang ${ }^{1 \dagger}$, Qiubei Zhu ${ }^{2 \dagger}$, Hua He ${ }^{1 \dagger}$, Lei Jiang ${ }^{1}$, Qiang Qiang ${ }^{3}$, Liuhua Hu ${ }^{4 *}$, Guohan Hu , Ying Jiang ${ }^{1}$, Xuehua Ding ${ }^{1}$ and Yicheng Lu' ${ }^{1 *}$

\section{Erratum}

Unfortunately, the original version of this article [1] contained an error in Fig. 9. Fig. 9b was used for both $9 \mathrm{~b}$ and $9 \mathrm{~d}$ and $9 \mathrm{~d}$ was not included. The correct version of Fig. 9 can be found below.

\begin{abstract}
Author details
'Department of Neurosurgery, Changzheng Hospital, Second Military Medical University, Shanghai 200003, China. ${ }^{2}$ Department of Otolaryngology,

Changzheng Hospital, Second Military Medical University, Shanghai 200003,

China. ${ }^{3}$ Department of Neurology, Huadong Hospital, Fudan University,

Shanghai 200040, China. ${ }^{4}$ Department of Cardiology, Ren Ji Hospital, School

of Medicine, Shanghai Jiao Tong University, Shanghai 200127, China.
\end{abstract}

Received: 12 January 2016 Accepted: 12 January 2016

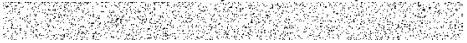

\section{References}

1. Zhang C, Zhu Q, He H, Jiang L, Qiang Q, Hu L, et al. RIZ1: a potential tumor suppressor in glioma. BMC Cancer. 2015;15:990. doi:10.1186/s12885-015-2023-1.

\footnotetext{
*Correspondence: iam565@126.com; luyc305@163.com

${ }^{\dagger}$ Equal contributors

${ }^{4}$ Department of Cardiology, Ren Ji Hospital, School of Medicine, Shanghai Jiao Tong University, Shanghai 200127, China

'Department of Neurosurgery, Changzheng Hospital, Second Military Medical University, Shanghai 200003, China

Full list of author information is available at the end of the article
}

Submit your next manuscript to BioMed Central and we will help you at every step:

- We accept pre-submission inquiries

- Our selector tool helps you to find the most relevant journal

- We provide round the clock customer support

- Convenient online submission

- Thorough peer review

- Inclusion in PubMed and all major indexing services

- Maximum visibility for your research

Submit your manuscript at www.biomedcentral.com/submit
() Biomed Central 


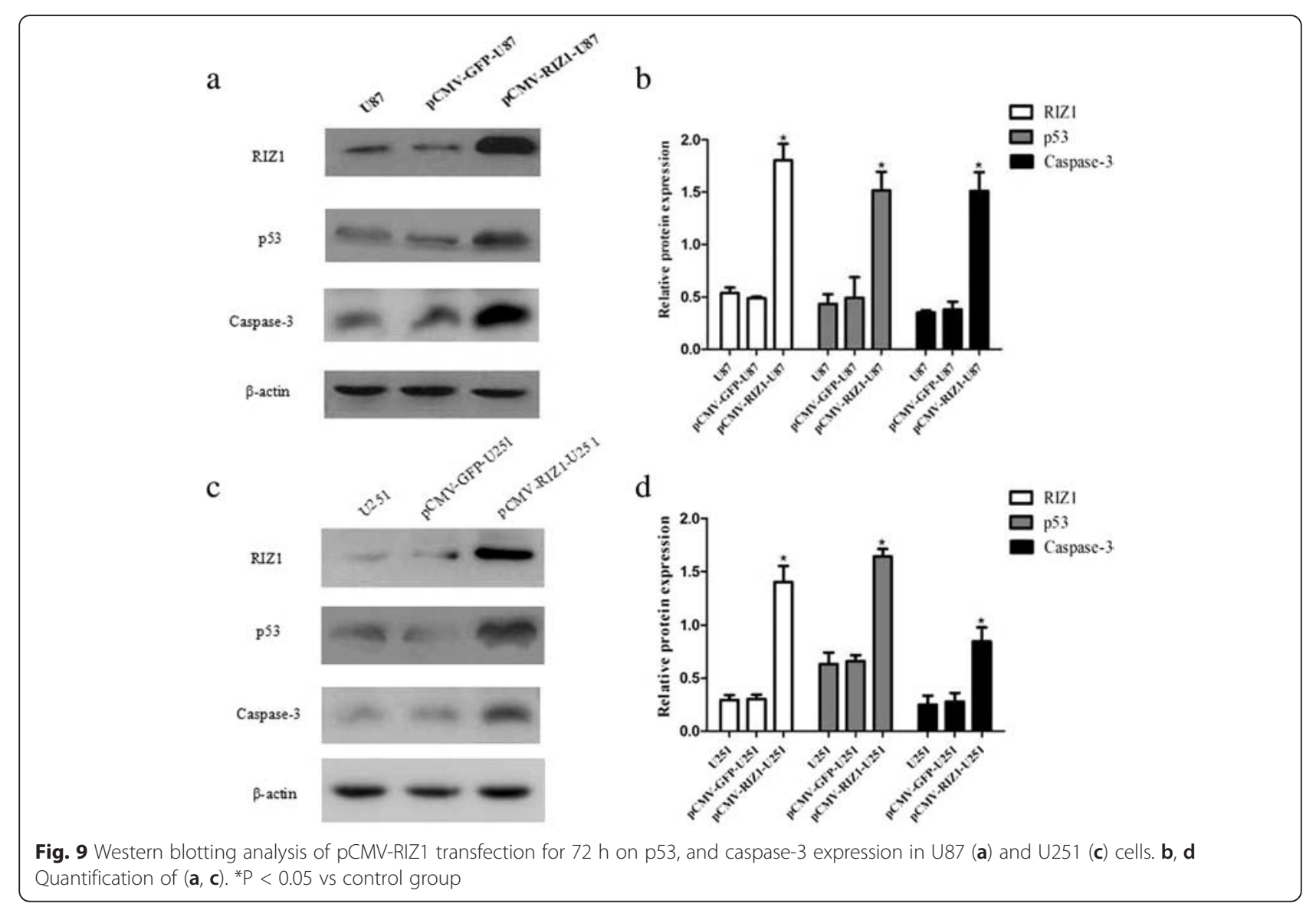

